Article

\title{
Toward Rational Design of Novel Anti-Cancer Drugs Based on Targeting, Solubility, and Bioavailability Exemplified by 1,3,4-Thiadiazole Derivatives Synthesized Under Solvent-Free Conditions
}

\author{
Huda R.M. Rashdan $1, *\left(\mathbb{0}\right.$, Mohammad M. Farag ${ }^{2}$, Marwa S. El-Gendey ${ }^{3,4}$ and \\ Marwa M. Mounier 5 \\ 1 Chemistry of Natural and Microbial Products Department, Pharmaceutical and Drug Industries Research \\ Division, National Research Centre, Dokki, Cairo 12622, Egypt \\ 2 Glass Research Department, National Research Centre, 33 El-Behooth Str., Dokki, Cairo 12622, Egypt \\ 3 Chemistry Department, Faculty of Science "Girls", Al-Azhar University, Cairo 11754, Egypt \\ 4 Chemistry Department, Faculty of College, Turabah, Taif University, Taif 21974, Saudi Arabia \\ 5 Pharmacognosy Department, Pharmaceutical and Drug Industries Research Division, National Research \\ Centre, Dokki, Cairo 12622, Egypt \\ * Correspondence: hr.rashdan@nrc.sci.eg; Tel.: +20-233-371-211; Fax: +20-233-370-931
}

Received: 31 May 2019; Accepted: 19 June 2019; Published: 27 June 2019

\begin{abstract}
The 1,3,4-thiadiazole derivatives (9a-i) were synthesized under solvent free conditions and their chemical composition was confirmed using different spectral tools (IR, Mass, and NMR spectrometry). All the synthesized compounds were screened for their anti-cancer potentiality over human breast carcinoma (MCF-7) and human lung carcinoma (A-549). Most of the tested compounds showed remarkable anti-breast cancer activity. However, compound 4 showed the most anti-lung cancer activity. Then, compounds with cytotoxic activity $\geq 80 \%$ over breast and lung cells were subjected to investigate their specificity on human normal skin cell line (BJ-1). Compounds $\mathbf{9 b}$ and $9 \mathrm{~g}$ were chosen owing to their high breast anti-cancer efficacy and their safety, in order to study the possible anti-cancer mode of action. Otherwise, drug delivery provides a means to overcome the low solubility, un-targeted release, and limited bioavailability of the prepared 1,3,4-thiadiazole drug-like substances. Compounds $\mathbf{9 b}$ and $\mathbf{9 g}$ were chosen to be encapsulated in Na-alginate microspheres. The release profile and mechanism of both compounds were investigated, and the results revealed that the release profiles of both microspheres showed a sustained release, and the release mechanism was controlled by Fickian diffusion. Accordingly, these compounds are promising for their use in chemotherapy for cancer treatment, and their hydrophilicity was improved by polymer encapsulation to become more effective in their pharmaceutical application.
\end{abstract}

Keywords: green chemistry; 1,3,4-thiadiazoles; 1,2,3-triazoles; anticancer activity; microspheres; drug delivery

\section{Introduction}

Cancer is one of the major causes of death today [1]. Usually, there are three main ways for treatment of cancer-Either individually or combined; surgery, chemotherapy, and radiation. Chemotherapy is a common method for cancer treatment [2].

Investigation of novel structures, designing and synthesis of some new, potent, and less toxic anti-cancer agents remains a major challenge for medical chemists.

The 1,3,4-Thiadiazoles- and 1,2,3-Triazole-based heterocycles have been well exploited for the production of many new medicinal scaffolds. While, the 1,3,4-Thiadiazole ring system is one of the 
most well-known important heterocyclic nuclei, as a core structural component, common and integral feature of a variety of biomedical agents and natural products. They attract considerable interest owing to their wide spectrum of biological and pharmaceutical applications. They have anti-tuberculosis, antibacterial, antihepatitis B viral, antifungal, antileishmanial, anti-inflammatory, CNS depressant, analgesic, anticancer, antioxidant, diuretic, molluscicidal, antihypertensive, analgesic, antimicrobial, antidiabetic, antitubercular, and anticonvulsant activities [3-9].

In applied synthesis, 1,2,3-triazoles become useful as building blocks and are additionally important due to their several therapeutically interesting activities $[10,11]$, including $\beta 3$-selective adrenergic receptor agonists [12], antimicrobial agents [13], anti-HIV compounds [14-17], kinase inhibitors [18,19], other enzymes inhibitors [20,21], cephalosporin cefatrizine [22], and $\beta$-lactam antibiotic tazobactam [23]. They are also stable in relation to light, oxygen, moisture and metabolic process [24,25].

Environmental protection and waste prevention have become the main requirements in an overcrowded world of demands, in order to ensure a healthy life free, from contaminants. Green chemistry techniques have proven their efficiency in terms of environmental impact using environmentally benign reactions. It has been conclusively proven that green reactions were preferred over the conventional thermal reactions that have originated from their ease of handling, rapidity, purities of products, enhancement in yields, and simplicity of the green methods compared with the thermal methods. One of these techniques is grinding reactions, in which organic reactions were done under solvent-free conditions [26]. Motivated by the statement; "The best solvent is no solvent [27]", we report here our solvent-free protocol for synthesis of new heterocycles of pharmaceutical and biochemical interest. Thus, some of the exothermic reactions could be achieved in excellent yields via grinding of the solids together or (solid/liquid) using the mortar pestle technique, known as grindstone chemistry. The reaction begins with grinding of the solids together with transfer of a small amount of energy by friction. Based on this simple technique, we synthesized a series of bioactive heterocycles.

As mentioned above, 1,3,4-thiadiazole compounds and their derivatives have showed potential therapeutic effect on different diseases. Nevertheless, the synthesis of therapeutic 1,3,4-thiadiazole derivatives, bearing 1,2,3-triazole moiety, by using grinding method, is considered a challenging issue.

Despite the previously mentioned wide spectrum biomedical and pharmaceutical application of 1,3,4-thiadiazole and 1,2,3-triazole compounds, heterocyclic compounds in general are poorly soluble in water, and hence, have poor bioavailability, and they almost removed from the blood stream quickly without performing their function, only a small fraction of the administered doses reached the circulatory system and hence the target organ. Consequently, they are preferred to be delivered to the tumor cells by attaching to a hydrophilic carrier to increase their bio-accessibility and chemo-sensitivity [28]. The common carriers for delivering water insoluble drugs are hydrophilic polymer carriers, such as alginate polymer. Alginate is a biocompatible natural hydrophilic polysaccharide polymer isolated from marine brown algae. It has been reported that it increases the wettability of hydrophobic drug molecules [29,30], and accordingly, it has been used successful in delivering and encapsulating thiadiazole-based compounds [31-34]. Generally, the encapsulation of drugs with polymers is one of the versatile methods in controlling drug release over a long period of time and solves the complications related to traditional drug administration methods in chemotherapy. Moreover, this encapsulation can decrease or diminish the toxicity of therapeutic molecules, resulting from their high released concentrations in the case of conventional administration methods. One of the versatile methods for drug encapsulation forms is the biodegradable polymer microspheres. The preparation of microspheres is easy, cost effective, and it has little environmental impact. Moreover, polymeric microspheres can encapsulate most kinds of drugs, from water soluble to water insoluble drugs.

This work aimed mainly to prepare a new series of potent anti-cancer compounds, using grinding solvent-free reactions, which are considered to be of special efficacy with serious simplifications and improvements over the conventional methods. In addition, two of these synthesized compounds were encapsulated in alginate polymer in a microsphere form to improve their release and therapeutic potential. The hydrophobic defect of these compounds was solved by their encapsulation in hydrophilic 
Na-alginate polymer microspheres formulation. The drug release profile from the microspheres and the release mechanism were assessed.

\section{Results and Discussion}

\subsection{Chemistry}

Condensation of 3-(1-(4-bromophenyl)-5-methyl-1H-1,2,3-triazol-4-yl)-1-phenyl-1H-pyrazole-4carbaldehyde (2) with methyl hydrazinecarbodithioate (3) by grinding method at room temperature afforded the desired compound methyl 2-((3-(1-(4-bromophenyl)-5-methyl-1H-1,2,3-triazol-4-yl)-1phenyl-1H-pyrazol-4-yl)methylene)hydrazine-1-carbodithioate (4). Structure of 4 was inferred from its spectral and micro-analytical data, its IR spectrum revealed the presence of the characteristic band for $\mathrm{NH}$ group and found it devoid of any bands for carbonyl group of $\mathrm{CHO}$. In addition, its ${ }^{1} \mathrm{H}$ NMR spectrum recorded a singlet signal at $\delta=13.34 \mathrm{ppm}$ for NH. Also, the structure was supported by mass spectra, which agree with the molecular formula (see Experimental part). The chemical composition of 4 was also confirmed via chemical transformation. Where, it was reacted with a series of selected derivatives of hydrazonoyl halides by grinding in the presence of 2-3 drops of DIPEA ( $N, N$-Diisopropylethylamine) to give products assigned as 1-5-(3-(1(4-bromophenyl)-5-methyl-1H-1,2,3-triazol-4-yl)-1-phenyl-1H-pyrazol-4yl)methylene)hydrazono)-4 (substituted)-4,5-dihydro-1,3,4-thiadiazol-2-yl) derivatives (9a-i) (Scheme 1) based on their spectral and micro-analytical data. The IR spectra of 9a-i revealed absorption bands at $1680-1730 \mathrm{~cm}^{-1}$ owing to the carbonyl stretching bands while the absorption bands of the $\mathrm{NH}$ groups were disappeared. ${ }^{1} \mathrm{H}$ NMR spectrum of $9 \mathrm{a}$ for example showed signals at $\delta=1.32\left(\mathrm{t}, 3 \mathrm{H}, J=7.5 \mathrm{~Hz}, \mathrm{CH}_{2} \mathrm{CH}_{3}\right), 4.35(\mathrm{q}$, $\left.2 \mathrm{H}, J=7.5 \mathrm{~Hz}, \mathrm{CH}_{2} \mathrm{CH}_{3}\right)$. Furthermore, ${ }^{13} \mathrm{C}$ NMR spectrum of 9a showed signals at $\delta=14.43\left(\mathrm{CH}_{3}\right)$, $63.20\left(\mathrm{CH}_{2}\right), 118.26-149.85(\mathrm{Ar}-\mathrm{C}), 158.48 \mathrm{ppm}(\mathrm{C}=\mathrm{O}) .{ }^{1} \mathrm{H}$ NMR spectrum of $9 \mathrm{f}$ showed signals at $\delta=2.37\left(\mathrm{~s}, 3 \mathrm{H}, \mathrm{CH}_{3}\right), 2.51\left(\mathrm{~s}, 3 \mathrm{H}, \mathrm{CH}_{3}\right)$. Its ${ }^{13} \mathrm{C}$ NMR spectrum showed signals at $\delta=21.12\left(\mathrm{CH}_{3}\right), 25.45$ $\left(\mathrm{CH}_{3}\right), 118.31-144.34$ (Ar-C), 165.5 ppm $(\mathrm{C}=\mathrm{O})$ (see Experimental part).

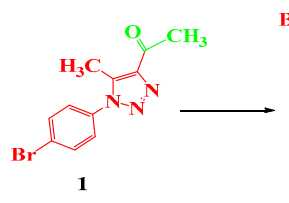<smiles>CC(C)CC1CC1</smiles>

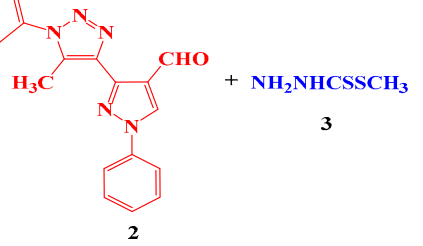

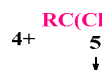<smiles>[CH][AsH]</smiles>
$(\stackrel{\oplus}{\ominus}$ 6

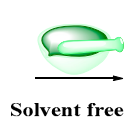<smiles>C=CNc1ccccc1C</smiles>

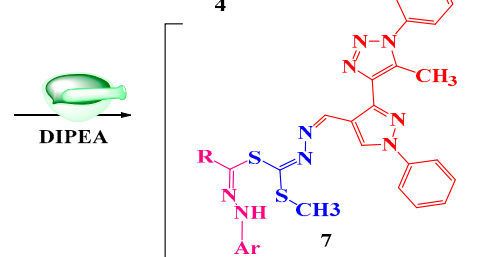
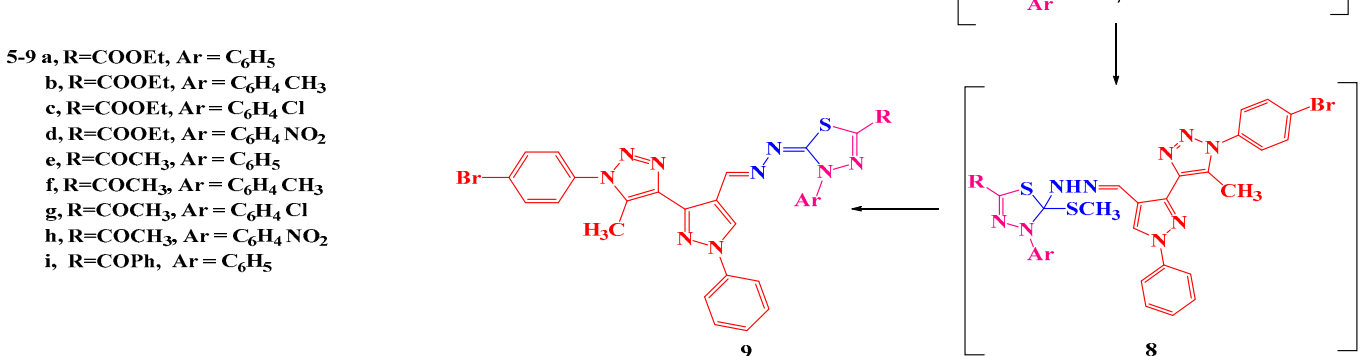

Scheme 1. The mechanism for the formation of $\mathbf{9 a - i}$.

Focusing on the preceding results, the mechanism outlined in Scheme 1 seems to be the most acceptable pathway for the formation of $\mathbf{9 a}-\mathbf{i}$. The reaction involved the initial formation of thiohydrazonate 7 , which submitted to intermolecular cyclization as soon as it was formed to yield the intermediate 8 or through 1,3-dipolar cycloaddition of nitrilimine 6 (which was prepared in situ 
from 5 with DIPEA) to the double bond $(\mathrm{C}=\mathrm{S})$ of 4 . Finally, compound 8 was converted to 9 via the elimination of the methyl mercaptan group.

\subsection{Anti-Cancer Activity}

A total of 12 compounds were screened for their cytotoxic potentiality over human breast carcinoma (MCF-7 cell line) and human lung carcinoma (A-549 cell line) as shown in Figure 1. Compounds 4, 9h, 9d, 9g, 2, 9c, 9i, 9e, and 9b, showed remarkable anti-cancer activity on breast cells with 96.4, 92.6, 92.3, $89.2,88.4,87.3,83.5,83.4$, and $81.9 \%$ of cytotoxic activity, respectively. While compound 4 showed the most anti-cancer activity on lung cells with $90.8 \%$. Afterwards, these compounds, which possessed $\geq 80 \%$ anti-cancer activity over breast and lung cells, were subjected to testing of their safety on human normal cell line (BJ-1) (Figure 2). Compound $\mathbf{9 b}, \mathbf{9 i}$ and $\mathbf{9 g}$ possessed high specificity with minimum toxicity on normal skin cells with $38.2,40.3$, and 40.7 of toxicity, respectively.

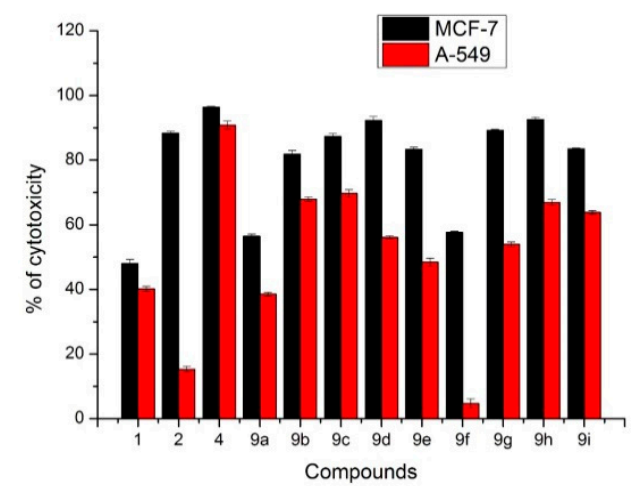

Figure 1. Screening the cytotoxic activities of compounds, in vitro, against human tumor cell lines: breast carcinoma (MCF-7) and human lung carcinoma (A-549 cell line). Preliminary concentration for screening was $100 \mathrm{ppm}$. Each result is a mean of 3 replicate samples.

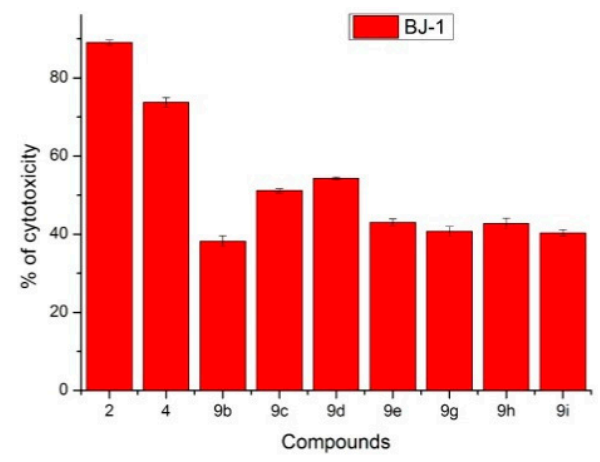

Figure 2. Screening the cytotoxic activities of active compounds, in vitro, against skin human normal cell line (BJ-1). Preliminary concentration for screening was $100 \mathrm{ppm}$. Each result is a mean of 3 replicate samples.

Compounds $9 \mathrm{~b}$ and $9 \mathrm{~g}$ were chosen due to their high breast anticancer activity and their safety in elucidating the possible anticancer mode of action.

$\mathrm{Bcl} 2$ family protein included the anti-apoptotic protein $\mathrm{Bcl}-2$ and proapoptotic protein Bax, which have been reported to regulate the induction of intrinsic apoptosis through mitochondria. Breast cancer cells were treated with compound $9 \mathrm{~b}$ and $9 \mathrm{~g}$ at different concentrations to determine the $\mathrm{LC}_{50}$ value of compound $\mathbf{9 b}$ and $9 \mathrm{~g}$. Afterwards, BCL2, BAX and BAX/BCL2 ratios were estimated by treated breast cells with 19.8 and $26.2 \mu \mathrm{g} / \mathrm{mL}^{\prime \prime}$ the $\mathrm{LC}_{50}$ value" of compound $9 \mathbf{b}$ and $9 \mathrm{~g}$ respectively. Compound $9 \mathbf{b}$ and $9 \mathrm{~g}$ possessed upregulate of BAX protein level and downregulate of BCL2 protein level with statistically significant $(p<0.05)$. As well, compound $\mathbf{9 b}$ and $\mathbf{9 g}$ disturb the ratio BAX/BCL2, which signal the apoptotic cascade inside the cells (Figure 3 ) and (Table 1). 


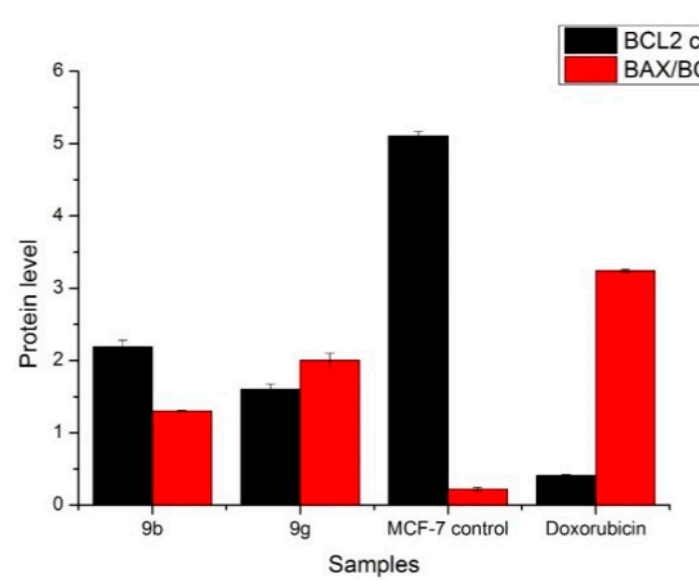

Figure 3. Bcl2 protein level $(\mathrm{ng} / \mathrm{mL})$ and BAX/BCL2 ratio of MCF-7treated with $\mathrm{IC}_{50}$ of compound $\mathbf{9 b}$ $(19.8 \mu \mathrm{g} / \mathrm{mL})$ and $\mathrm{IC}_{50}$ of $\mathbf{9 g}(26.2 \mu \mathrm{g} / \mathrm{mL})$ compared to untreated cells and cells treated with reference drug Doxorubicin. $p<0.05$ in $9 \mathbf{b}$ and $9 g$.

Table 1. BAX protein level $(\mathrm{Pg} / \mathrm{mL})$ of MCF-7treated with $\mathrm{IC}_{50}$ of compound $\mathbf{9 b}(19.8 \mu \mathrm{g} / \mathrm{mL})$ and $\mathrm{IC}_{50}$ of $9 \mathrm{~g}(26.2 \mu \mathrm{g} / \mathrm{mL})$ compared to untreated cells and cells treated with reference drug Doxorubicin.

\begin{tabular}{cc}
\hline & BAX CONC. \\
\hline $\mathbf{9 b}$ & 160.5 \\
$\mathbf{9 g}$ & 241.7 \\
cont. & 40.743 \\
Doxorubicin & 259.2 \\
\hline
\end{tabular}

The effect of compounds $\mathbf{9 b}$ and $\mathbf{9 g}$ on DNA fragmentation were studied as well, MCF-7 was treated with 19.8 and $26.2 \mu \mathrm{g} / \mathrm{mL}$ of compound $\mathbf{9 b}$, and $9 \mathrm{~g}$ respectively and \% of DNA fragmentation were determined (Figure 4). Compound $\mathbf{9 b}$ and $\mathbf{9 g}$ upregulate the protein level of caspase 7 in comparison with untreated cells with significant difference $(p<0.05)$. While, $\mathbf{9 b}$ and $\mathbf{9} \mathbf{g}$ induce apoptotic cascades inside cells through the activation of effector caspase 7 protein (Figure 5).

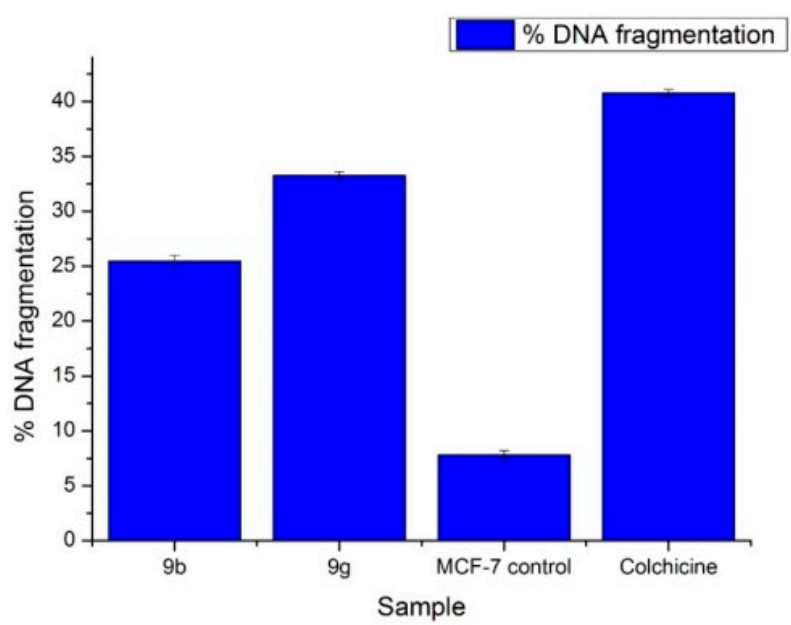

Figure 4. The percentage DNA fragmentation of treated cells with $\mathrm{IC}_{50}$ of compound $9 \mathbf{b}(19.8 \mu \mathrm{g} / \mathrm{mL})$ and $\mathrm{IC}_{50}$ of $9 \mathrm{~g}(26.2 \mu \mathrm{g} / \mathrm{mL})$ compared to untreated control cells and cells treated with reference drug Colchicine $(p<0.05)$. 


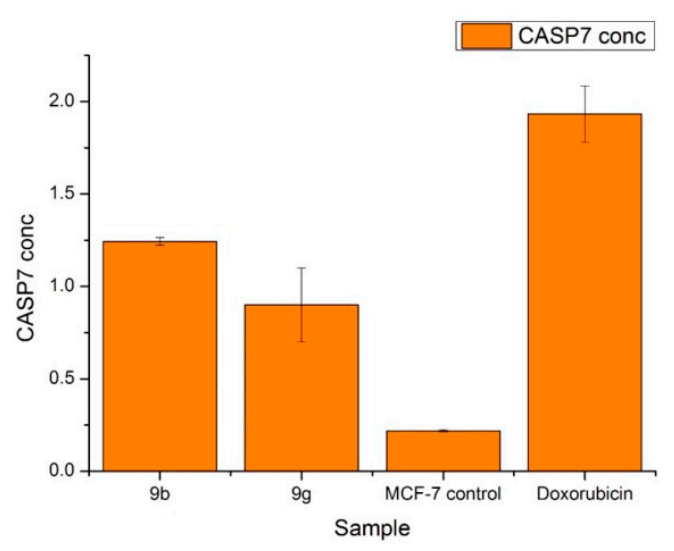

Figure 5. Casp7 (ng/mL) quantitative estimation of MCF-7 treated with $\mathrm{IC}_{50}$ of compound $\mathbf{9 b}$ (19.8 $\mu \mathrm{g} / \mathrm{mL})$ and $\mathrm{IC}_{50}$ of $9 \mathrm{~g}(26.2 \mu \mathrm{g} / \mathrm{mL})$ compared to untreated cells and cells treated with reference to the drug Doxorubicin $(p<0.05)$.

\subsection{Microspheres Encapsulation}

Compounds $\mathbf{9 b}$ and $\mathbf{9 g}$ were chosen as examples to be encapsulated in Na-alginate microspheres, the samples were encoded after encapsulation as $\mathbf{M 9 b}$, and $\mathbf{M 9 g}$, respectively and the blank microspheres encoded as $\mathbf{B}$.

\subsection{Morphology and Size of Microspheres}

The morphology and diameter of prepared microspheres were determined from SEM micrographs (Figure 6). As shown in the Figure 6, the microspheres were spherical with rough surfaces. Moreover, the mean diameter values of microspheres, measured from SEM micrographs, were $38 \mu \mathrm{m}, 24 \mu \mathrm{m}$, and $47 \mu \mathrm{m}$ for $\mathbf{B}, \mathbf{M} 9 \mathbf{b}$, and $\mathbf{M 9 g}$ samples, respectively. As a consequence, M9b microspheres showed the smallest diameters, while M9g microspheres demonstrated the biggest ones. This can be attributed to the chemical composition of the encapsulated heterocyclic compounds. The chemical structure of $9 \mathbf{b}$ contained the $\mathrm{Cl}$ atom, which is highly electronegative. As a result, there was a likely repulsion force generated among carboxylic and hydroxyl groups in the polymer chains and the $\mathrm{Cl}^{-}$ions in $9 \mathrm{~g}$ compound.

\subsection{Thermal Gravimetric Analysis (TGA)}

Figure 7 represents the TGA curves of $\mathbf{B}, \mathbf{M 9 b}$, and $\mathbf{M 9 g}$ samples. All the curves of different microspheres showed three weight loss stages. The first on (stage I) was observed before $200^{\circ} \mathrm{C}$, which can be attributed to the elimination of water molecules, adsorbed on the polymeric microspheres. The second one (stage II) was observed between $200{ }^{\circ} \mathrm{C}$ and $350{ }^{\circ} \mathrm{C}$. This weight loss was assigned to thermal decomposition of the polymer. The third weight loss (stage III) was observed from $350{ }^{\circ} \mathrm{C}$ to $680^{\circ} \mathrm{C}$, due to the complete decomposition of alginate polymer. Remarkably, the percentages of weight losses of $\mathbf{M 9 b}$ and $\mathbf{M 9 g}$ microspheres were higher than that of blank microspheres (sample B), which was evident during stage III. This was explained by the removal and decomposition of encapsulated $9 \mathrm{~b}$ and $9 \mathrm{~g}$ chemical compounds. 

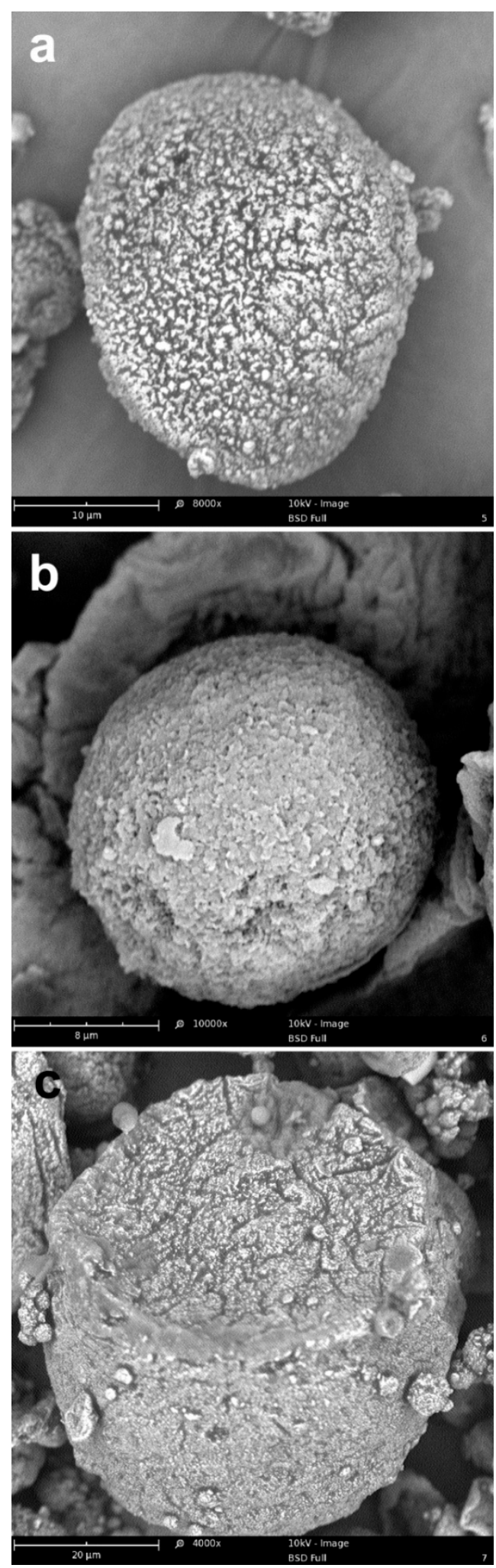

Figure 6. SEM micrographs of B microspheres (a), M9b (b) and M9g (c). 


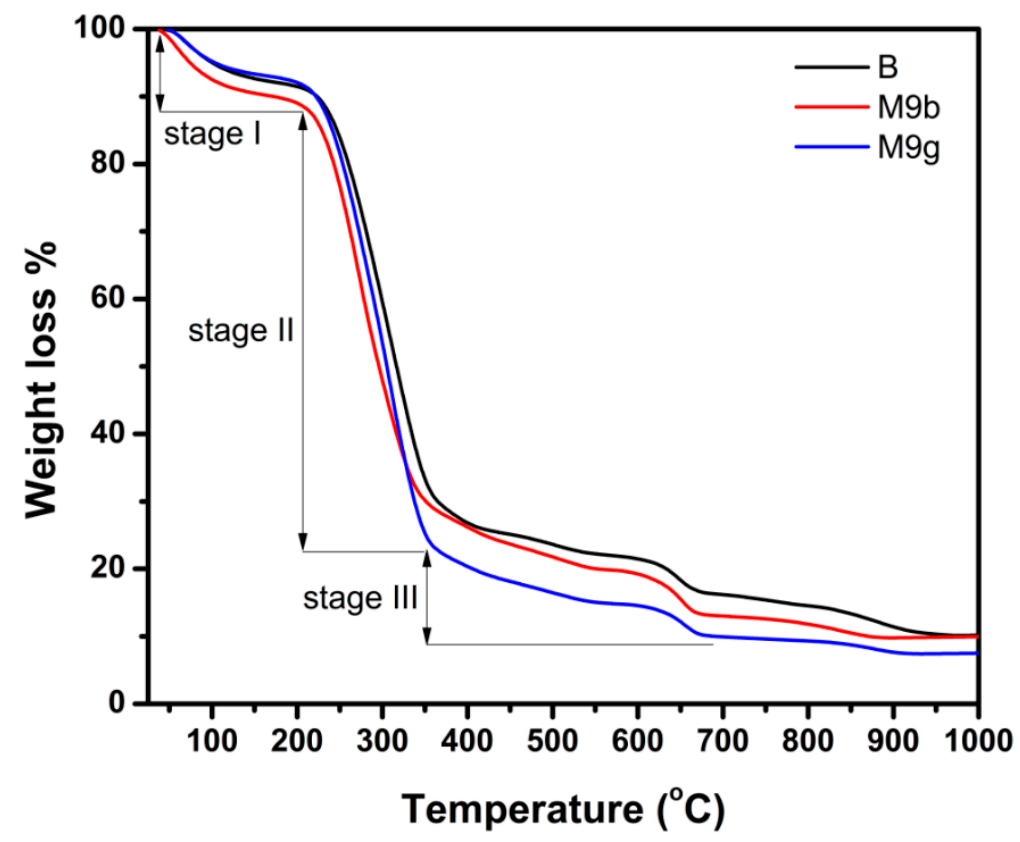

Figure 7. Thermal gravimetric analysis (TGA) analysis of $\mathbf{B}, \mathbf{M 9 b}$ and $\mathbf{M 9 g}$ microspheres.

\subsection{Antitumor Activity of $\mathbf{M 9 b}$ and $\mathbf{M 9 g}$ over Breast Cancer Cell Line (MCF-7)}

M9b and M9g were screened for their cytotoxic potentiality on the breast cancer cell line (MCF-7) on the same concentration used in their corresponding compounds $\mathbf{9 b}$ and $\mathbf{9 g}$. Both $\mathbf{M 9 b}$ and $\mathbf{M 9 g}$ showed moderate activity 48.4 , and $45.7 \%$, respectively, after $48 \mathrm{~h}$ treatment. Meanwhile, $\mathbf{M} 9 \mathrm{~b}$ and $\mathbf{M 9 g}$ showed no toxicity on normal cell line BJ-1, which refer to the safety and selectivity of $\mathbf{M} 9 \mathbf{b}$ and M9g.

\subsection{Drug Release Profile and Kinetics}

The amounts of encapsulated chemical compounds were approximately equal, the values were; $7.8 \mu \mathrm{g} / \mathrm{mg}$ and $7.0 \mu \mathrm{g} / \mathrm{mg}$ of $\mathbf{M 9 b}$, and $\mathbf{M 9 g}$ microspheres, respectively. However, a slightly lower encapsulated amount of $9 \mathrm{~g}$ in alginate microsphere was likely to be attributed to the presence of $\mathrm{Cl}$ atom in the chemical structure of compound $9 \mathrm{~g}$, which increased the electronegativity and hence the repulsion among it, and carboxyl and hydroxyl groups in alginate chains. Figure 8a,b show the amounts $(\mu \mathrm{g})$, and the percentages of released drugs, respectively, for $\mathbf{M 9 b}$ and $\mathbf{M 9 g}$ samples. Generally, the release profiles of $\mathbf{M 9 b}$ and $\mathbf{M 9 g}$ microspheres showed a sustained release in two stages. The first release stage was fast and occurred during the initial $6 \mathrm{~h}$ of immersion, while the second one was slow and occurred throughout the rest of the incubation period (from $6 \mathrm{~h}$ to $144 \mathrm{~h}$ ). The amounts of released molecules after $6 \mathrm{~h}$ of immersion were $104 \pm 6.9$ and $96 \pm 5.7 \mu \mathrm{g}$, and the percentages were $26 \pm 1.9 \%$ and $21 \pm 1.6 \%$ form $\mathbf{M 9 b}$, and $\mathbf{M 9 g}$, respectively. In contrast, the released amounts at the end of incubation time were $180 \pm 12.5 \mu \mathrm{g}$ and $275 \pm 17.1 \mu \mathrm{g}$, and the percentages were $50 \pm 3.5 \%$ and $78 \pm 4.9 \%$ form $\mathbf{M 9 b}$, and $\mathbf{M 9 g}$, respectively. According to the cell viability tests, the initial released amounts of both compounds $\mathbf{M 9 b}$ and $\mathbf{M 9 g}$ were considered effective and the potential to diminish the cancer cells under investigation (human breast carcinoma (MCF-7 cell line)). 

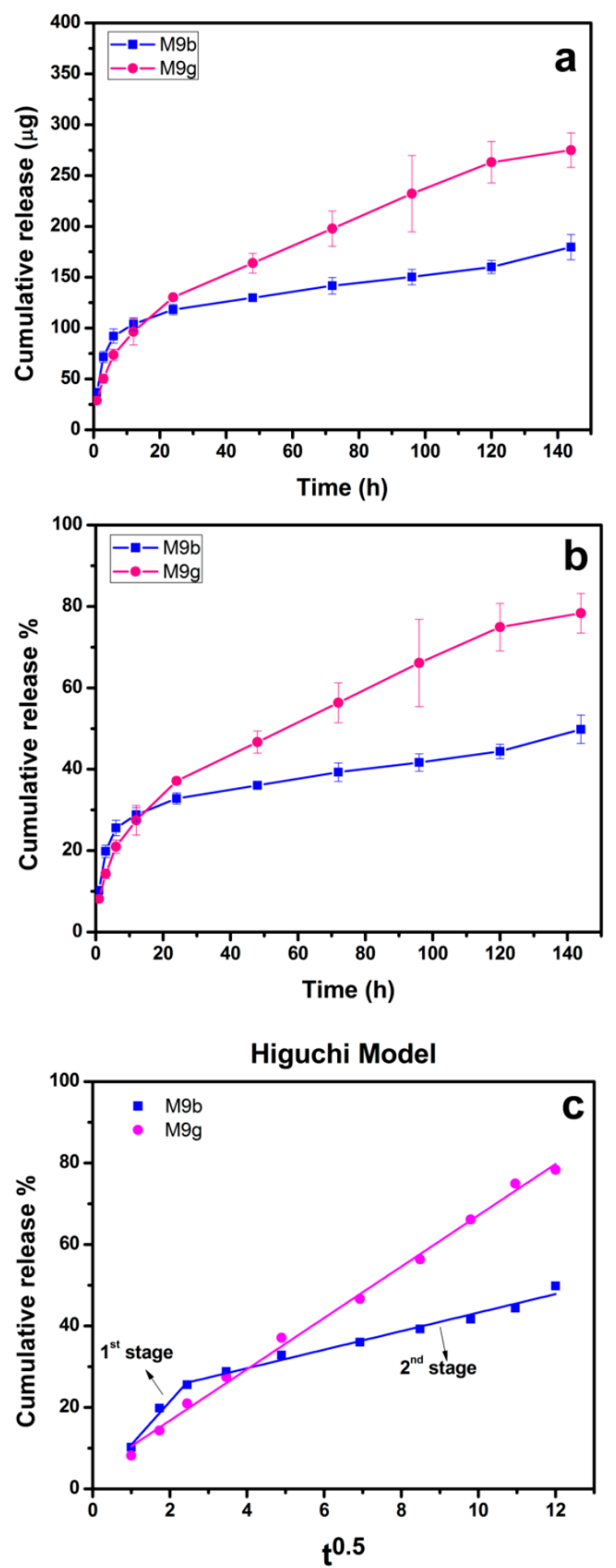

Figure 8. (a) Cumulative release amount $(\mu \mathrm{g})$, (b) cumulative release $\%$, and (c) fitting of release data with Higuchi model for M9b and M9g microspheres.

The mechanism of drug release was investigated by linear fitting of the data with Higuchi model (Figure 8c). The degree of linearity was determined from regression coefficient $\left(\mathrm{R}^{2}\right)$, Higuchi constant, $\mathrm{k}\left(\mathrm{h}^{-0.5}\right)$ calculated as well. Form the figure it was noted that there were two release rates of $\mathbf{M 9 b}$ sample. The first one was fast release with $k=10.59 h^{-0.5}\left(R^{2}=0.961\right)$, which occurred during the first $6 \mathrm{~h}$ of immersion, while the second one was slow release and occurred throughout the rest of incubation time with $\mathrm{k}=2.27 \mathrm{~h}^{-0.5}\left(\mathrm{R}^{2}=0.978\right)$. In contrast, $\mathbf{M 9 g}$ was released in one step with 
$k=6.30 h^{-0.5}\left(R^{2}=0.995\right)$. Accordingly, the release rate of the chemical compounds depended on the chemical structure of both compounds. Furthermore, the high value of $\mathrm{R}^{2}$ for all fittings indicated that the release mechanism was controlled by Fickian diffusion.

\section{Experimental}

\subsection{Chemistry}

Experimental Instrumentation

All melting points were determined on an electrothermal apparatus and are uncorrected. IR spectra were recorded ( $\mathrm{KBr}$ discs) on a Shimadzu FT-IR $8201 \mathrm{PC}$ spectrophotometer. ${ }^{1} \mathrm{H}$ NMR and ${ }^{13} \mathrm{C}$ NMR spectra were recorded in $\left(\mathrm{CD}_{3}\right)_{2} \mathrm{SO}$ solutions on BRUKER 400 FT-NMR system spectrometer and chemical shifts are expressed in ppm units using TMS as an internal reference. Mass spectra were recorded on a GC-MS QP1000 EX Shimadzu. Elemental analyses were carried out at the Microanalytical Center of Cairo University. 1-(1-(4-bromophenyl)-5-methyl-1H-1,2,3-triazol-4-yl)ethanone (1) [35]. 3-(1-(4-bromophenyl)-5-methyl-1H-1,2,3-triazol-4-yl)-1-phenyl-1 $H$-pyrazole-4-carbaldehyde (2) [11], methyl hydrazinecarbodithioate (3) [36] and hydrazonoyl halides 5a-i [37-39] were prepared as previously reported.

\subsection{Synthesis}

3.2.1. Methyl 2-((3-(1-(4-bromophenyl)-5-methyl-1H-1,2,3-triazol-4-yl)-1-phenyl-1H-pyrazol-4-yl)methylene) hydrazine-1-carbodithioate (4)

A mixture of 3-(1-(4-bromophenyl)-5-methyl-1H-1,2,3-triazol-4-yl)-1-phenyl-1H-pyrazole-4carbaldehyde (2) and methyl hydrazinecarbodithioate (3) $(5 \mathrm{mmol})$ was thoroughly ground with a pestle in an open mortar at room temperature for $3-5 \mathrm{~min}$ until the mixture turned into a melt. The initial syrup grinding proceeded for 5-10 min, and the reaction was monitored by TLC. The solid was washed with water and recrystallized from ethanol to give the corresponding methyl hydrazinecarbodithioate derivative 4.

Grey Crystals, Yield: 92\%, m.p.: 156-158 ${ }^{\circ} \mathrm{C}$; FT-IR $\left(\mathrm{KBr}^{\mathrm{cm}}{ }^{-1}\right)$ : $v 2982(\mathrm{C}-\mathrm{H}), 3119(\mathrm{NH}), 1625$ $(\mathrm{C}=\mathrm{N}), 1612(\mathrm{C}=\mathrm{C}) ;{ }^{1} \mathrm{H}$ NMR $\left(400 \mathrm{MHz}, \mathrm{DMSO}-d_{6}\right): \delta 2.52\left(\mathrm{~s}, 3 \mathrm{H}, \mathrm{CH}_{3}\right), 2.63\left(\mathrm{~s}, 3 \mathrm{H}, \mathrm{CH}_{3}\right), 7.3-8.03(\mathrm{~m}$, 9H, Ar-H), 8.97 (s, 1H, CH=N), 8.98 (s, 1H, C-H pyrazole), 13.34 (s, 1H, NH); MS: $m / z$ [\%]: $511\left(\mathrm{M}^{+}, 17\right)$, 496 (22), 450 (18), 378 (3), 273 (21), 250 (36), 177 (100), 165 (18), 77 (90), 55 (43). Analysis: calcd. For $\mathrm{C}_{21} \mathrm{H}_{18} \mathrm{BrN}_{7} \mathrm{~S}_{2}$ (511): C, 49.22; H, 3.54; N, 19.13\%. Found: C, 49.35; H, 3.45; N, 19.05\%.

\subsubsection{General Procedures for Synthesis of $\mathbf{9 a}-\mathbf{i}$}

Methyl hydrazinecarbodithioate derivative $4(2.5 \mathrm{~g}, 5 \mathrm{mmol})$ and the appropriate hydrazonoyl halides $5 \mathbf{a}-\mathbf{i}(5 \mathrm{~m} \mathrm{~mol})$ with the addition of 2-3 drops of DIPEA, were mixed and ground with a pestle in an open mortar at room temperature for 3-5 min until the mixture turned into a melt. The initial syrup grinding proceeded for 5-10 $\mathrm{min}$, and the reaction was monitored by TLC (Thin Layer Chromatography). The solid was washed with water, then ethanol, and recrystallized from acetic acid to give $9 \mathbf{a}-\mathbf{i}$, respectively.

Ethyl 5-((-(3-(1-(4-bromophenyl)-5-methyl-1H-1,2,3-triazol-4-yl)-1-phenyl-1H-pyrazol-4-yl)methylene) hydrazono)-4-phenyl-4,5-dihydro-1,3,4-thiadiazole-2-carboxylate (9a) Yellow Crystals, Yield: 89\%, m.p.: 196-198 ${ }^{\circ} \mathrm{C}$; FT-IR (KBr, cm $\left.{ }^{-1}\right)$ : $v 2987(\mathrm{C}-\mathrm{H}), 1725(\mathrm{C}=\mathrm{O}), 1630(\mathrm{C}=\mathrm{N}), 1600(\mathrm{C}=\mathrm{C}) ;{ }^{1} \mathrm{H}$ NMR $(400 \mathrm{MHz}$, DMSO- $\left.d_{6}\right): \delta 1.32\left(\mathrm{t}, 3 \mathrm{H}, \mathrm{CH}_{2} \mathrm{CH}_{3}\right), 2.51\left(\mathrm{~s}, 3 \mathrm{H}, \mathrm{CH}_{3}\right), 4.35\left(\mathrm{q}, 2 \mathrm{H}, \mathrm{CH}_{2}\right), 7.38-8.01(\mathrm{~m}, 15 \mathrm{H}, \mathrm{Ar}-\mathrm{H}$, $\mathrm{CH}=\mathrm{N}), 9.02$ (s, $1 \mathrm{H}, \mathrm{C}-\mathrm{H}$ pyrazole); ${ }^{13} \mathrm{C}$ NMR $\left(100 \mathrm{MHz}\right.$, DMSO- $\left.d_{6}\right): \delta 10.34,14.43,63.20,118.26,119.17$, $122.84,123.37,127.63,129.54,133.14,135.40,138.45,139.02,144.34,149.85,158.48 ; \mathrm{MS}: \mathrm{m} / \mathrm{z}$ [\%]: 656 (M+2, 37), 654 (50), 639 (12), 624 (9), 611 (18), 578 (5), 530(6), 482 (21), 430 (12), 377 (13), 278 (2), 265 (3), 
178 (80), 160 (10), 66 (90), 50 (100). Analysis: calcd. For $\mathrm{C}_{30} \mathrm{H}_{24} \mathrm{BrN}_{9} \mathrm{O}_{2} \mathrm{~S}$ (654): C, 55.05; H, 3.70; N, $19.26 \%$. Found: C, 55.12; H, 3.62; N, 19.17\%.

Ethyl 5-((-(3-(1-(4-bromophenyl)-5-methyl-1H-1,2,3-triazol-4-yl)-1-phenyl-1H-pyrazol-4-yl)methylene) hydrazono)-4-(p-tolyl)-4,5-dihydro-1,3,4-thiadiazole-2-carboxylate (9b). Yellow Crystals, Yield: 93\%, m.p.: 205-207 ${ }^{\circ} \mathrm{C}$; FT-IR $\left(\mathrm{KBr}, \mathrm{cm}^{-1}\right)$ : v $2991(\mathrm{C}-\mathrm{H}), 1727(\mathrm{C}=\mathrm{O}), 1620(\mathrm{C}=\mathrm{N}), 1610(\mathrm{C}=\mathrm{C}) ;{ }^{1} \mathrm{H}$ NMR $(400 \mathrm{MHz}$, DMSO- $\left.d_{6}\right): \delta 1.37\left(\mathrm{t}, 3 \mathrm{H}, \mathrm{CH}_{2} \mathrm{CH}_{3}\right), 2.58\left(\mathrm{~s}, 3 \mathrm{H}, \mathrm{CH}_{3}\right), 2.64\left(\mathrm{~s}, 3 \mathrm{H}, \mathrm{CH}_{3}\right), 4.22\left(\mathrm{q}, 2 \mathrm{H}, \mathrm{CH}_{2} \mathrm{CH}_{3}\right), 7.5-8.13$ (m, 14H, Ar-H, CH=N), 9.12 (s, 1H, C-H pyrazole); MS: m/z [\%]: $667\left(\mathrm{M}^{+}, 12\right), 653$ (15), 637 (1), 622 (9), 608 (22), 560 (15), 527(16), 482 (21), 430 (12), 270 (21), 267 (13), 176 (11), 166 (19), 70 (100). Analysis: calcd. For $\mathrm{C}_{31} \mathrm{H}_{26} \mathrm{BrN}_{9} \mathrm{O}_{2} \mathrm{~S}$ (667): C, 55.69; $\mathrm{H}, 3.92 ; \mathrm{N}, 18.86 \%$. Found: $\mathrm{C}, 55.58 ; \mathrm{H}, 3.81 ; \mathrm{N}, 18.85 \%$.

Ethyl 5-((-(3-(1-(4-bromophenyl)-5-methyl-1H-1,2,3-triazol-4-yl)-1-phenyl-1H-pyrazol-4-yl)methylene) hydrazono)-4-(4-chlorophenyl)-4,5-dihydro-1,3,4-thiadiazole-2-carboxylate (9c). Yellow Crystals, Yield: 85\%, m.p.: $220-222{ }^{\circ} \mathrm{C}$; FT-IR $\left(\mathrm{KBr}, \mathrm{cm}^{-1}\right)$ : $v 2982(\mathrm{C}-\mathrm{H}), 1730(\mathrm{C}=\mathrm{O}), 1622(\mathrm{C}=\mathrm{N}), 1612(\mathrm{C}=\mathrm{C}) ;{ }^{1} \mathrm{H}$ NMR $\left(400 \mathrm{MHz}, \mathrm{DMSO}-d_{6}\right): \delta 1.33\left(\mathrm{t}, 3 \mathrm{H}, \mathrm{CH}_{2} \mathrm{CH}_{3}\right), 2.59\left(\mathrm{~s}, 3 \mathrm{H}, \mathrm{CH}_{3}\right), 4.35\left(\mathrm{q}, 2 \mathrm{H}, \mathrm{CH}_{2} \mathrm{CH}_{3}\right), 7.15-8.95(\mathrm{~m}$, 13H, Ar-H), 8.97 (s, 1H, CH=N), 9.04 (s, 1H, C-H pyrazole); MS: $m / z$ [\%]: $687\left(\mathrm{M}^{+}, 3\right), 642$ (17), $612(21)$, 610 (2), 572 (19), $532(6), 491$ (11), 430 (12), 270 (21), 272 (43), 180 (18), 167 (19), 55 (100). Analysis: calcd. For $\mathrm{C}_{30} \mathrm{H}_{23} \mathrm{BrClN}_{9} \mathrm{O}_{2} \mathrm{~S}$ (687): C, 52.30; H, 3.36; N, 18.30\%. Found: C, 52.25; H, 3.31; N, $18.19 \%$.

Ethyl 5-(((3-(1-(4-bromophenyl)-5-methyl-1H-1,2,3-triazol-4-yl)-1-phenyl-1H-pyrazol-4-yl)methylene) hydrazono)-4-(4-nitrophenyl)-4,5-dihydro-1,3,4-thiadiazole-2-carboxylate (9d). Yellow Crystals, Yield: 83\%, m.p.: $255-257^{\circ} \mathrm{C}$; FT-IR $\left(\mathrm{KBr}, \mathrm{cm}^{-1}\right)$ : $v 2977(\mathrm{C}-\mathrm{H}), 1727(\mathrm{C}=\mathrm{O}), 1628(\mathrm{C}=\mathrm{N}), 1600(\mathrm{C}=\mathrm{C}) ;{ }^{1} \mathrm{H}$ NMR (400 MHz, DMSO- $\left.d_{6}\right): \delta 1.32\left(\mathrm{t}, 3 \mathrm{H}, \mathrm{CH}_{2} \mathrm{CH}_{3}\right), 2.56\left(\mathrm{~s}, 3 \mathrm{H}, \mathrm{CH}_{3}\right), 4.30\left(\mathrm{q}, 2 \mathrm{H}, \mathrm{CH}_{2} \mathrm{CH}_{3}\right), 7.11-8.85(\mathrm{~m}$, 14H, Ar-H CH=N), 8.98 (s, 1H, C-H pyrazole); MS: m/z [\%]: $699\left(\mathrm{M}^{+}, 53\right), 672$ (8), 651 (15), 640 (25), 602 (7), 600 (21), 565 (14), 537 (16), 480 (21), 412 (12), 278 (24), 266 (33), 186 (8), 177 (100), 65 (50). Analysis: calcd. For $\mathrm{C}_{30} \mathrm{H}_{23} \mathrm{BrN}_{10} \mathrm{O}_{4} \mathrm{~S}$ (699): $\mathrm{C}, 51.51 ; \mathrm{H}, 3.31 ; \mathrm{N}, 20.02 \%$. Found: $\mathrm{C}, 51.58 ; \mathrm{H}, 3.27 ; \mathrm{N}, 19.95 \%$.

1-(5-((-(3-(1-(4-Bromophenyl)-5-methyl-1H-1,2,3-triazol-4-yl)-1-phenyl-1H-pyrazol-4-yl)methylene)hydrazono) -4-phenyl-4,5-dihydro-1,3,4-thiadiazol-2-yl)ethan-1-one (9e). Yellow Crystals, Yield: 91\%, m.p.: 199-201 ${ }^{\circ} \mathrm{C}$; FT-IR $\left(\mathrm{KBr}, \mathrm{cm}^{-1}\right): v 1685(\mathrm{C}=\mathrm{O}), 1630(\mathrm{C}=\mathrm{N}), 1597(\mathrm{C}=\mathrm{C}) ;{ }^{1} \mathrm{H}$ NMR $\left(400 \mathrm{MHz}, \mathrm{DMSO}-d_{6}\right): 2.51(\mathrm{~s}, 3 \mathrm{H}$, $\left.\mathrm{CH}_{3}\right), 2.57\left(\mathrm{~s}, 3 \mathrm{H}, \mathrm{CH}_{3}\right), 7.33-8.15(\mathrm{~m}, 14 \mathrm{H}, \mathrm{Ar}-\mathrm{H}), 9.02(\mathrm{~s}, 1 \mathrm{H}, \mathrm{CH}=\mathrm{N}), 9.05(\mathrm{~s}, 1 \mathrm{H}, \mathrm{C}-\mathrm{H}$ pyrazole); MS: $m / z$ [\%]: $624\left(\mathrm{M}^{+}, 27\right), 601$ (18), 591 (5), 570 (21), 523 (17), 500 (14), 485 (4), 465 (6), 432 (2), 381 (9), 280 (3), 256 (33), 180 (18), 176 (100), 66 (30). Analysis: calcd. For $\mathrm{C}_{29} \mathrm{H}_{22} \mathrm{BrN}_{9} \mathrm{OS}$ (624): C, 55.77; H, 3.55; N, 20.19\%. Found: C, 55.65; H, 3.42; N, 20.13\%.

1-(5-((-(3-(1-(4-bromophenyl)-5-methyl-1H-1,2,3-triazol-4-yl)-1-phenyl-1H-pyrazol-4-yl)methylene)hydrazono) -4-(p-tolyl)-4,5-dihydro-1,3,4-thiadiazol-2-yl)ethan-1-one (9f). Yellow Crystals, Yield: 91\%, m.p.: 285-287 ${ }^{\circ} \mathrm{C}$; FT-IR $\left(\mathrm{KBr}, \mathrm{cm}^{-1}\right): v 1680(\mathrm{C}=\mathrm{O}), 1635(\mathrm{C}=\mathrm{N}), 1611(\mathrm{C}=\mathrm{C}) ;{ }^{1} \mathrm{H}$ NMR $\left(400 \mathrm{MHz}, \mathrm{DMSO}-d_{6}\right): 2.37(\mathrm{~s}, 3 \mathrm{H}$, $\left.\mathrm{CH}_{3}\right), 2.51\left(\mathrm{~s}, 3 \mathrm{H}, \mathrm{CH}_{3}\right), 2.63\left(\mathrm{~s}, 3 \mathrm{H}, \mathrm{CH}_{3}\right), 7.37-8.05(\mathrm{~m}, 13 \mathrm{H}, \mathrm{Ar}-\mathrm{H}), 9.02(\mathrm{~s}, 1 \mathrm{H}, \mathrm{CH}=\mathrm{N}), 9.08(\mathrm{~s}, 1 \mathrm{H}$, C-H pyrazole); ${ }^{13} \mathrm{C}$ NMR (100 MHz, DMSO- $\left.d_{6}\right): \delta 10.32,21.12,25.45,118.31,119.25,123.10,127.61$, 130.01, 133.17, 135.41, 136.60, 138.41, 139.32, 144.34, 165.5; MS: $\mathrm{m} / z$ [\%]: $624\left(\mathrm{M}^{+}, 27\right), 601$ (18), 591 (5), 570 (21), 523 (17), 500 (14), 485 (4), 465 (6), 432 (2), 381 (9), 280 (3), 256 (33), 180 (18), 176 (100), 66 (30). Analysis: calcd. For $\mathrm{C}_{29} \mathrm{H}_{24} \mathrm{BrN}_{9} \mathrm{OS}(637)$ : $\mathrm{C}, 56.43 ; \mathrm{H}, 3.79 ; \mathrm{N}, 19.74 \%$. Found: $\mathrm{C}, 56.32 ; \mathrm{H}, 3.73 ; \mathrm{N}$, $19.65 \%$.

1-(5-((-(3-(1-(4-Bromophenyl)-5-methyl-1H-1,2,3-triazol-4-yl)-1-phenyl-1H-pyrazol-4-yl)methylene)hydrazono) -4-(4-chlorophenyl)-4,5-dihydro-1,3,4-thiadiazol-2-yl)ethan-1-one (9g). Yellow Crystals, Yield: 89\%, m.p.: 212-214 ${ }^{\circ} \mathrm{C}$; FT-IR $\left(\mathrm{KBr}, \mathrm{cm}^{-1}\right): v 1686(\mathrm{C}=\mathrm{O}), 1620(\mathrm{C}=\mathrm{N}), 1601(\mathrm{C}=\mathrm{C}) ;{ }^{1} \mathrm{H}$ NMR $\left(400 \mathrm{MHz}, \mathrm{DMSO}-d_{6}\right)$ : $2.53\left(\mathrm{~s}, 3 \mathrm{H}, \mathrm{CH}_{3}\right), 2.61\left(\mathrm{~s}, 3 \mathrm{H}, \mathrm{CH}_{3}\right), 7.41-8.36(\mathrm{~m}, 14 \mathrm{H}, \mathrm{Ar}-\mathrm{H}, \mathrm{CH}=\mathrm{N}), 9.08$ (s, 1H, C-H pyrazole); MS: $\mathrm{m} / z$ [\%]: $660(\mathrm{M}+2,12), 658\left(\mathrm{M}^{+}, 18\right), 632$ (3), 605 (1), $590(15), 578$ (31), 543 (19), 509 (25), 486 (14), 463 (16), 427 (12), 391 (91), 287 (32), 257 (30), 190 (8), 177 (100), 60 (52). Analysis: calcd. For $\mathrm{C}_{29} \mathrm{H}_{21} \mathrm{BrClN}_{9} \mathrm{OS}$ (658): C, 52.86; H, 3.21; N, 19.13\%. Found: C, 52.93; H, 3.16; N, 19.02\%. 
1-(5-((-(3-(1-(4-Bromophenyl)-5-methyl-1H-1,2,3-triazol-4-yl)-1-phenyl-1H-pyrazol-4-yl)methylene)hydrazono) -4-(4-nitrophenyl)-4,5-dihydro-1,3,4-thiadiazol-2-yl)ethan-1-one (9h). Yellow Crystals, Yield: 95\%, m.p.: 218-220 ${ }^{\circ} \mathrm{C}$; FT-IR (KBr, cm $\left.{ }^{-1}\right): v 1680(\mathrm{C}=\mathrm{O}), 1625(\mathrm{C}=\mathrm{N}), 1600(\mathrm{C}=\mathrm{C}) ;{ }^{1} \mathrm{H}$ NMR $\left(400 \mathrm{MHz}, \mathrm{DMSO}-d_{6}\right)$ : 2.57 (s, 3H, CH $\left.\mathrm{CH}_{3}\right), 2.63\left(\mathrm{~s}, 3 \mathrm{H}, \mathrm{CH}_{3}\right), 7.31-8.39(\mathrm{~m}, 14 \mathrm{H}, \mathrm{Ar}-\mathrm{H}, \mathrm{CH}=\mathrm{N}), 8.96$ (s, 1H, C-H pyrazole); MS: $m / z$ [\%]: $669\left(\mathrm{M}^{+}, 28\right), 652(30), 639$ (21), 623 (9), 607 (6), 593 (2), 590 (35), $580(14), 534$ (29), 518 (2), 480 (41), 465 (61), 430 (12), 397 (1), 282 (23), 259 (32), 197 (18), 178 (90), 50 (100). Analysis: calcd. For $\mathrm{C}_{29} \mathrm{H}_{21} \mathrm{BrN}_{10} \mathrm{O}_{3} \mathrm{~S}$ (669): C, 52.03; H, 3.16; N, 20.92\%. Found: C, 52.12; H, 3.01; N, $20.87 \%$.

(-5-((-(3-(1-(4-bromophenyl)-5-methyl-1H-1,2,3-triazol-4-yl)-1-phenyl-1H-pyrazol-4-yl)methylene)hydrazono) -4-phenyl-4,5-dihydro-1,3,4-thiadiazol-2-yl)(phenyl)methanone (9i). Brownish Yellow Crystals, Yield: 86\%, m.p.: 230-232 ${ }^{\circ} \mathrm{C}$; FT-IR (KBr, cm $\left.{ }^{-1}\right)$ : v 1687 (C=O), 1633 (C=N), 1609 (C=C); ${ }^{1} \mathrm{H}$ NMR $(400 \mathrm{MHz}$, DMSO-d $): 2.53$ (s, 3H, CH CH$_{3}, 7.17-8.98(\mathrm{~m}, 19 \mathrm{H}, \mathrm{Ar}-\mathrm{H}), 9.08(\mathrm{~s}, 1 \mathrm{H}, \mathrm{CH}=\mathrm{N}), 9.14$ (s, 1H, C-H pyrazole); MS: $m / z$ [\%]: $686\left(\mathrm{M}^{+}, 33\right), 671$ (3), 592 (27), 525 (19), 459 (16), 393 (32), 281 (13), 266 (37), 195 (100), 177 (20), 55 (60). Analysis: calcd. For $\mathrm{C}_{34} \mathrm{H}_{24} \mathrm{BrN}_{9} \mathrm{OS}$ (686): C, 59.48; H, 3.16; $3.52 \mathrm{~N}, 18.36 \%$. Found: C, 59.35; H, 3.13; N, 18.31\%.

\subsection{Anti-Cancer Activity}

\subsubsection{Cell Lines}

Human breast carcinoma (MCF-7 cell line), human lung carcinoma (A-549 cell line) and skin normal human cell line (BJ-1); "a telomerase immortalized normal foreskin fibroblast cell line" were obtained from Karolinska Center, Department of Oncology and Pathology, Karolinska Institute and Hospital, Stockholm, Sweden.

\subsubsection{Cell Culture}

The procedure was carried out in a sterile area using a laminar air flow cabinet biosafety class II level. The culture was maintained in RPMI 1640 medium with 1\% antibiotic-antimycotic mixture (10,000 U/mL potassium penicillin, 10,000 $\mathrm{gg} / \mathrm{mL}$ streptomycin sulfate and $25 \mu \mathrm{g} / \mathrm{mL}$ amphotericin B), $1 \%$ L-glutamine, and supplemented with $10 \%$ heat inactivated fetal bovine serum. Culturing and sub culturing were carried out according to Thabrew et al. [40]. Doxorubicin was used as a positive control. A negative control, composed of DMSO, was also used.

\subsubsection{Cell Viability Assay}

This was done according to Selim et al. [41], as described by Mosmann [42]. The cells were seeded at concentration of $10 \times 10^{3}$ cells per well in case of MCF-7, $20 \times 10^{3}$ cells/well in case of A-549 cell lines and $35-45 \times 10^{3}$ cells/well in case of BJ-1 using 96 -well plates at $37^{\circ} \mathrm{C}$. After $48 \mathrm{~h}$ of incubation, the medium was aspirated and $40 \mu \mathrm{L}$ MTT salt $(2.5 \mathrm{mg} / \mathrm{mL})$ were added and further incubated for $4 \mathrm{~h}$. Then, $200 \mu \mathrm{L} \mathrm{10 \%} \mathrm{sodium} \mathrm{dodecyl} \mathrm{sulphate} \mathrm{(SDS)} \mathrm{was} \mathrm{added.} \mathrm{The} \mathrm{absorbance} \mathrm{was} \mathrm{measured} \mathrm{at}$ $595 \mathrm{~nm}$.

\subsubsection{Determination of $\mathrm{IC}_{50}$ Values}

$\mathrm{IC}_{50}$ values were calculated, using a probit analysis, and by utilizing the SPSS computer program (SPSS for windows, statistical analysis software package/version 9/1989 SPSS Inc., Chicago, IL, USA).

\subsubsection{Measurement of DNA Fragmentation using DPA Assay}

DNA fragmentation of the cells was assayed, as described by Cohen and Duke \& Burton $[43,44]$. Briefly, the cells were lysed with lysis buffer containing $20 \mathrm{mM}$ EDTA, 0.5\% (v/v) Triton X-100, and 5 mivi Tris ( $\mathrm{pH} \mathrm{8.0)} \mathrm{for} 15 \mathrm{~min}$ on ice. The cells were then centrifuged for $20 \mathrm{~min}$, at $27,000 \times g$, to separate intact chromatin (pellet) from DNA fragments (supernatant). The amount of DNA in both the pellet and the supernatant was measured by using a diphenylamine reagent. The optical density is a 
colorimetric, measured at $600 \mathrm{~nm}$. The percentage of DNA fragmentation was calculated as the ratio of DNA in supernatant and DNA in pellet.

\subsubsection{Human CASP7 (Caspase 7) Estimation}

The micro ELISA plate provided in this kit pre-coated with CASP7 specific antibody. A biotinylated CASP7 antibody and Avidin-Horseradish Peroxidase (HRP) conjugate was added. The excess components were aspired. The substrate solution was then added. The wells, which contained CASP7, biotinylated detection antibody and Avidin-HRP conjugate will appear blue in color. The color turned yellow following the addition of sulfuric acid solution. The optical density (OD) was measured at a wavelength of $450 \mathrm{~nm} \pm 2 \mathrm{~nm}$ [45].

\subsubsection{Measurement of BCl-2 Levels}

BCL-2 in the samples and standards were estimated according to Barbareschi et al. [46]. A biotin-conjugated antibody was added followed by streptavidin-HRP. The reaction is then terminated by adding acid and absorbance was measured at $450 \mathrm{~nm}$.

\subsubsection{Measurement of Bax Levels}

Bax protein levels were evaluated according to Onur et al. [47]. Monoclonal antibody, specific to Bax captured on the plate, was added. After incubation, Streptavidin conjugated to Horseradish peroxidase was added. The reaction was then terminated by adding acid and optical density of the color produced measured at $450 \mathrm{~nm}$ [47].

\subsection{Encapsulation in Na-alginate Microspheres}

Microspheres, encapsulated by compounds $\mathbf{9 b}$ and $\mathbf{9 g}$, were prepared by w/o emulsion and internal gelation method [48]. For microsphere synthesis, the following method was carried out; $5 \%$ $(w / v)$ sodium alginate (from Sigma company, New Delhi, India) solution was prepared by dissolution of the polymer in distilled water. The solutions of both compounds $9 \mathbf{b}$ and $9 \mathbf{g}$ were prepared by dissolving them separately in DMSO solvent with a concentration of $10 \mathrm{mg} / \mathrm{mL}$. After the complete dissolution of polymers, the compounds $\mathbf{9 b}$ and $\mathbf{9 g}$ were added to the polymer solution individually with volume ratio 1:4 (the microsphere samples were coded as $\mathbf{M 9 b}$ and $\mathbf{M 9 g}$ ). Thereafter, $10 \%$ of Span ${ }^{\circledR} 85$ and paraffin oil (five times of the total volume) were added to the above solutions and stirred at $1000 \mathrm{rpm}$ at $70{ }^{\circ} \mathrm{C}$ for $15 \mathrm{~min}$, and then $\mathrm{CaCl}_{2}$ of $2 \mathrm{M}$ concentration was added to the mixtures with volume ratio 1:5 and stirred for an additional $15 \mathrm{~min}$ at the same stirring speed and temperature. The solutions were suddenly cooled at $4{ }^{\circ} \mathrm{C}$. The obtained microspheres were washed with isopropanol several times, to remove the paraffin oil, centrifuged and dried. For comparison, the microspheres without chemical compounds were prepared following the above protocol (coded as B). The morphology and thermal behavior of microspheres were determined by SEM (HITACHI SU 8000, Tokyo, Japan), and TGA (TGA Q500), respectively. On the other hand, the amounts of encapsulated $\mathbf{9 b}$ and $9 \mathrm{~g}$ in alginate microspheres were determined by dissolving $10 \mathrm{mg}$ of microspheres in $5 \mathrm{~mL}$ DMSO and the concentrations of $\mathbf{9 b}$ and $\mathbf{9 g}$ were determined by UV-VIS spectroscopy.

\subsection{In Vitro Release Test}

The release behavior of the synthetic chemical compounds encapsulated in Na-alginate microspheres (samples $\mathbf{M 9 b}$ and $\mathbf{M 9 g}$ ) was investigated by immersing $50 \mathrm{mg}$ of microspheres in $4.5 \mathrm{~mL}$ of phosphate buffer saline (PBS) with $\mathrm{pH}$ 7.4. The drug release was evaluated at $37^{\circ} \mathrm{C}$ up to 6 days. At each predetermined time $(1,3,6,12 \mathrm{~h}, 1,2,3,4,5$, and $6 \mathrm{~d}), 1.5 \mathrm{~mL}$ of immersed solution was collected and replaced by $1.5 \mathrm{~mL}$ fresh one. The collected solutions were kept at $-20^{\circ} \mathrm{C}$ up until the measurement. The concentrations of released drug were determined by measuring the absorbance by 
UV/VIS spectroscopy at wavelength $355 \mathrm{~nm}$ and plotting it on the standard curve. This wavelength was determined from the maxima in UV/VIS absorption curve using Jasco.

\subsection{Drug Releasing Mechanism}

The drug release mechanism was investigated by fitting the drug release profiles to the Higuchi model. This model was used extensively to define the diffusion controlled processes of released drug from the porous carrier [49]. This model is given by the following equation:

$$
\mathrm{Q}=\mathrm{k} \cdot \mathrm{t}^{0.5}
$$

where, $Q$ is the percentage of drug released at time $t$, and $k$ is the release rate constant.

\subsection{Statistical Analysis}

All experimental data stated in this work were expressed as the average \pm standard deviation (SD) for $\mathrm{n}=3$ and were analyzed using standard analysis of Student's t-test. The level of significance ( $p$-value) is set at $<0.05$.

\section{Conclusions}

In this described investigation, a series of 1,3,4-Thiadiazole derivatives bearing 1,2,3-triazole moiety, were introduced as a new class of anti-cancer agents. The scaffolds have the advantage of synthetic protocol approachability.

Briefly, our target compounds were prepared through reaction of methyl 2-((3-(1-(4-bromophenyl)5-methyl-1H-1,2,3-triazol-4-yl)-1-phenyl-1H-pyrazol-4-yl)methylene)hydrazine-1-carbodithioate (4) with selective derivatives of hydrazonoyl halides via eco-friendly grinding clean method under solvent free conditions. Compounds $9 \mathrm{~b}$ and $\mathbf{9 g}$ have anti-cancer effects on breast cancer with safety effects on normal cells. Compound $\mathbf{9 b}$ and $\mathbf{9 g}$ induce apoptosis inside the cells by disturbing the balance between pro-apoptotic and anti-apoptotic protein, and increase the percentage DNA fragmentation, which triggers signals to activate Caspase 7. In turn this plays an executionary role in apoptosis. Furthermore, $9 \mathrm{~b}$ and $9 \mathrm{~g}$ were chosen to be encapsulated in Na-alginate microspheres, the encapsulation of selected compounds in alginate microspheres controlled their release, so that the release sustained, and the release mechanism was controlled by Fickian diffusion.

Accordingly, this work introduced new promising anti-cancer agents for chemotherapy, and solved the defects associated with their water poor solubility, and hence, poor bioavailability, by encapsulating in hydrophilic Na-alginate microspheres to increase the hydrophilicity. This formulation controlled the release of chemical compounds into the solution to a sustained release.

Author Contributions: H.R.M.R. and M.S.E.-G. designed and synthesized the new organic compounds using eco-friendly method, and they confirmed the chemical composition of these compounds using physical and chemical analyses. M.M.M. evaluated the anticancer potency, mode of action elucidation techniques, and the toxicity of the newly synthesized compounds. M.M.F. encapsulated the selected compounds in Na-alginate microspheres and studied their release profile and kinetics. All authors analyzed the data and wrote the final manuscript.

Funding: This research received no external funding.

Conflicts of Interest: The authors declare no conflict of interests regarding the publication of this paper.

\section{References}

1. Rahib, L.; Smith, B.D.; Aizenberg, R.; Rosenzweig, A.B.; Fleshman, J.M.; Matrisian, L.M. Projecting cancer incidence and deaths to 2030: The unexpected burden of thyroid, liver, and pancreas cancers in the United States. Cancer Res. 2014, 74, 2913-2921. [CrossRef] [PubMed]

2. Vogus, D.R.; Krishnan, V.; Mitragotri, S. A review on engineering polymer drug conjugates to improve combination chemotherapy. Curr. Opin. Colloid Interface Sci. 2017, 31, 75-85. [CrossRef] 
3. Zhang, L.-J.; Yang, M.-Y.; Sun, Z.-H.; Tan, C.-X.; Weng, J.-Q.; Wu, H.-K.; Liu, X.-H. Synthesis and antifungal activity of 1,3,4-thiadiazole derivatives containing pyridine group. Lett. Drug Des. Discov. 2014,11,1107-1111. [CrossRef]

4. Yan, S.-L.; Yang, M.-Y.; Sun, Z.-H.; Min, L.-J.; Tan, C.-X.; Weng, J.-Q.; Wu, H.-K.; Liu, X.-H. Synthesis and antifungal activity of 1,2,3-thiadiazole derivatives containing 1,3,4-thiadiazole moiety. Lett. Drug Des. Discov. 2014, 11, 940-943. [CrossRef]

5. Tong, J.-Y.; Sun, N.-B.; Wu, H.-K. Synthesis, crystal structure and biological activity of N-(5-(O-tolyl)-1,3,4-thiadiazol-2-yl) cyclopropanecarboxamide. J. Chem. Soc. Pak. 2013, 35, 1351-1355.

6. Yang, M.-Y.; Zhao, W.; Sun, Z.-H.; Tan, C.-X.; Weng, J.-Q.; Liu, X.-H. Synthesis and biological activity of acylthiourea derivatives contain 1,2,3-thiadiazole and 1,3,4-thiadiazole. Lett. Drug Des. Discov. 2015, 12, 314-318. [CrossRef]

7. Li, Z.; Wang, X.; Da, Y. Synthesis of 2-(5-(2-chlorophenyl)-2-furoylamido)-5-aryloxymethyl-1,3,4-thiadiazoles under microwave irradiation. Synth. Commun. 2001, 31, 1829-1836. [CrossRef]

8. Liu, X.-H.; Shi, Y.-X.; Ma, Y.; Zhang, C.-Y.; Dong, W.-L.; Pan, L.; Wang, B.-L.; Li, B.-J.; Li, Z.-M. Synthesis, antifungal activities and 3D-QSAR study of N-(5-substituted-1,3,4-thiadiazol-2-yl) cyclopropanecarboxamides. Eur. J. Med. Chem. 2009, 44, 2782-2786. [CrossRef]

9. Ahmad, T.; Singh, A.K.; Jaiswal, N.; Singh, D. Synthesis and Pharmacological Activity of 1,3,4-Thiadiazole Derivatives. ChemInform 2012, 43, 30. [CrossRef]

10. Abdelhamid, A.O.; El-Idreesy, T.T.; Abdelriheem, N.A.; Dawoud, H.R.M. Green One-Pot Solvent-Free Synthesis of Pyrazolo[1,5-a]pyrimidines, Azolo[3,4- $d$ ]pyridiazines, and Thieno[2,3-b]pyridines Containing Triazole Moiety. J. Heterocycl. Chem. 2016, 53, 710-718. [CrossRef]

11. Rashdan, H.R.M.; Gomha, S.M.; El-Gendey, M.S.; El-Hashash, M.A.; Soliman, A.M.M. Eco-friendly one-pot synthesis of some new pyrazolo[1,2- $b]$ phthalazinediones with antiproliferative efficacy on human hepatic cancer cell lines. Green Chem. Lett. Rev. 2018, 11, 264-274. [CrossRef]

12. Brockunier, L.L.; Parmee, E.R.; Ok, H.O.; Candelore, M.R.; Cascieri, M.A.; Colwell, L.F., Jr.; Deng, L.; Feeney, W.P.; Forrest, M.J.; Hom, G.J. Human $\beta 3$-adrenergic receptor agonists containing 1,2,3-triazole-substituted benzenesulfonamides. Bioorganic Med. Chem. Lett. 2000, 10, 2111-2114. [CrossRef]

13. Wang, Z.-J.; Gao, Y.; Hou, Y.-L.; Zhang, C.; Yu, S.-J.; Bian, Q.; Li, Z.-M.; Zhao, W.-G. Design, synthesis, and fungicidal evaluation of a series of novel 5-methyl-1H-1,2,3-trizole-4-carboxyl amide and ester analogues. Eur. J. Med. Chem. 2014, 86, 87-94. [CrossRef] [PubMed]

14. Brik, A.; Muldoon, J.; Lin, Y.C.; Elder, J.H.; Goodsell, D.S.; Olson, A.J.; Fokin, V.V.; Sharpless, K.B.; Wong, C.H. Rapid diversity-oriented synthesis in microtiter plates for in situ screening of HIV protease inhibitors. ChemBioChem 2003, 4, 1246-1248. [CrossRef] [PubMed]

15. Whiting, M.; Muldoon, J.; Lin, Y.C.; Silverman, S.M.; Lindstrom, W.; Olson, A.J.; Kolb, H.C.; Finn, M.; Sharpless, K.B.; Elder, J.H. Inhibitors of HIV-1 protease by using in situ click chemistry. Angew. Chem. Int. Ed. 2006, 45, 1435-1439. [CrossRef] [PubMed]

16. Biorn, A.C.; Cocklin, S.; Madani, N.; Si, Z.; Ivanovic, T.; Samanen, J.; Van Ryk, D.I.; Pantophlet, R.; Burton, D.R.; Freire, E. Mode of action for linear peptide inhibitors of HIV-1 gp120 interactions. Biochemistry 2004, 43, 1928-1938. [CrossRef] [PubMed]

17. Tornøe, C.W.; Christensen, C.; Meldal, M. Peptidotriazoles on solid phase:[1,2,3]-triazoles by regiospecific copper (I)-catalyzed 1,3-dipolar cycloadditions of terminal alkynes to azides. J. Org. Chem. 2002, 67, 3057-3064. [CrossRef]

18. Shah, D.B.; Ramanathan, M. Glycogen synthase kinase-3: A potential target for drug discovery in the treatment of neurodegenerative disorders. Curr. Enzym. Inhib. 2017, 13, 107-128. [CrossRef]

19. Olesen, P.H.; Sørensen, A.R.; Ursø, B.; Kurtzhals, P.; Bowler, A.N.; Ehrbar, U.; Hansen, B.F. Synthesis and in vitro characterization of 1-(4-aminofurazan-3-yl)-5-dialkylaminomethyl-1H-[1,2,3]triazole-4-carboxylic acid derivatives. A new class of selective GSK-3 inhibitors. J. Med. Chem. 2003, 46, 3333-3341. [CrossRef]

20. Krasiński, A.; Radić, Z.; Manetsch, R.; Raushel, J.; Taylor, P.; Sharpless, K.B.; Kolb, H.C. In situ selection of lead compounds by click chemistry: Target-guided optimization of acetylcholinesterase inhibitors. J. Am. Chem. Soc. 2005, 127, 6686-6692. [CrossRef]

21. Mocharla, V.P.; Colasson, B.; Lee, L.V.; Röper, S.; Sharpless, K.B.; Wong, C.H.; Kolb, H.C. In situ click chemistry: Enzyme-generated inhibitors of carbonic anhydrase II. Angew. Chem. 2005, 117, 118-122. [CrossRef] 
22. Syed, M.A.; Ramappa, A.K.; Alegaon, S. Synthesis and evaluation of antitubercular and anti fungal activity of some novel 6-(4-substituted aryl)-2-(3,5-dimethyl-1H-pyrazol-1-yl) imidazo[2,1-b][1,3,4] thiadiazole derivatives. Asian J. Pharm. Clin. Res. 2013, 6, 47-51.

23. Caballé, C.; Urdaneta, E.; Marzo, F.; Larralde, J.; Santidrián, S. Inhibition of in vitro intestinal absorption of D-galactose by cefroxadine, cefatrizine and cefaloglycin. Indian J. Pharmacol. 2003, 35, 163-167.

24. Totobenazara, J.; Burke, A.J. New click-chemistry methods for 1,2,3-triazoles synthesis: Recent advances and applications. Tetrahedron Lett. 2015, 56, 2853-2859. [CrossRef]

25. Krasiński, A.; Fokin, V.V.; Sharpless, K.B. Direct synthesis of 1,5-disubstituted-4-magnesio-1,2,3-triazoles, revisited. Org. Lett. 2004, 6, 1237-1240. [CrossRef] [PubMed]

26. Tanaka, K.; Toda, F. Solvent-free organic synthesis. Chem. Rev. 2000, 100, 1025-1074. [CrossRef] [PubMed]

27. Gedye, R.; Smith, F.; Westaway, K.; Ali, H.; Baldisera, L.; Laberge, L.; Rousell, J. The use of microwave ovens for rapid organic synthesis. Tetrahedron Lett. 1986, 27, 279-282. [CrossRef]

28. Merisko-Liversidge, E.; Liversidge, G.G.; Cooper, E.R. Nanosizing: A formulation approach for poorly-watersoluble compounds. Eur. J. Pharm. Sci. 2003, 18, 113-120. [CrossRef]

29. Shiraishi, S.; Imai, T.; Iwaoka, D.; Otagiri, M. Improvement of absorption rate of indomethacin and reduction of stomach irritation by alginate dispersions. J. Pharm. Pharmacol. 1991, 43, 615-620. [CrossRef]

30. Shiraishi, S.; Arahira, M.; Imai, T.; Otagiri, M. Enhancement of dissolution rates of several drugs by low-molecular chitosan and alginate. Chem. Pharm. Bull. 1990, 38, 185-187. [CrossRef]

31. Mondal, N.; Pal, T.K.; Ghosal, S.K. Development and validation of RP-HPLC method to determine letrozole in different pharmaceutical formulations and its application to studies of drug release from nanoparticles. Acta Pol. Pharm. 2009, 66, 11-17. [PubMed]

32. Dey, S.K.; Mandal, B.; Bhowmik, M.; Ghosh, L.K. Development and in vitro evaluation of Letrozole loaded biodegradable nanoparticles for breast cancer therapy. Braz. J. Pharm. Sci. 2009, 45, 585-591. [CrossRef]

33. Siddiqa, A.J.; Chaudhury, K.; Adhikari, B. Letrozole dispersed on poly (vinyl alcohol) anchored maleic anhydride grafted low density polyethylene: A controlled drug delivery system for treatment of breast cancer. Colloids Surf. B Biointerfaces 2014, 116, 169-175. [CrossRef] [PubMed]

34. Alemrayat, B.; Elhissi, A.; Younes, H.M. Preparation and characterization of letrozole-loaded poly(d,l-lactide) nanoparticles for drug delivery in breast cancer therapy. Pharm. Dev. Technol. 2018,1-8. [CrossRef] [PubMed]

35. Rashdan, H.R.; Roaiah, H.M.; Muhammad, Z.A.; Wietrzyk, J.; Milczarek, M.; Soliman, A.M. Design, efficient synthesis, mechanism of reaction and antiproliferative activity against cancer and normal cell lines of a novel class of fused pyrimidine derivatives. Acta Polooiae Pharm. Drug Res. 2018, 75, 679-688.

36. Klayman, D.L.; Bartosevich, J.F.; Griffin, T.S.; Mason, C.J.; Scovill, J.P. 2-Acetylpyridine thiosemicarbazones. 1. A new class of potential antimalarial agents. J. Med. Chem. 1979, 22, 855-862. [CrossRef] [PubMed]

37. Abdelhamid, A.O.; Fahmi, A.A.; Ali, A.B. Reactions with hydrazonoyl halides 66: Synthesis of some new 1,3,4-thiadiazoles, triazolino[4,3-a]pyrimidines and isoxazolo[3,4- $d$ ]pyridazines containing coumarin moiety. Eur. J. Chem. 2011, 2, 544-551. [CrossRef]

38. Abdelhamid, A.O.; Mohamed, G.S. Reactions with hydrazonoyl halides XXIV [1]: Synthesis of some new unsymmetrical azines and dihydro-1,3,4-thiadiazoles. Phosphorus Sulfur Silicon Relat. Elem. 1999, 152, 115-128. [CrossRef]

39. Abdelhamid, A.O.; Abdel-Riheem, N.A.; Emam, H.A. Reactions with Hydrazonoyl Halides. Part XXV. Synthesis of Some New 2,3-Dihydro-1,3,4-thiadiazoles and 5-Arylazothiazoles. J. Chem. Res. Synop. 1999, 9, 532-533. [CrossRef]

40. Thabrew, M.I.; HUGHES, R.D.; MCFARLANE, I.G. Screening of hepatoprotective plant components using a HepG2 cell cytotoxicity assay. J. Pharm. Pharmacol. 1997, 49, 1132-1135. [CrossRef]

41. Selim, M.S.; Amer, S.K.; Mohamed, S.S.; Mounier, M.M.; Rifaat, H.M. Production and characterisation of exopolysaccharide from Streptomyces carpaticus isolated from marine sediments in Egypt and its effect on breast and colon cell lines. J. Genet. Eng. Biotechnol. 2018, 16, 23-28. [CrossRef] [PubMed]

42. Mosmann, T. Rapid colorimetric assay for cellular growth and survival: Application to proliferation and cytotoxicity assays. J. Immunol. Methods 1983, 65, 55-63. [CrossRef]

43. Cohen, J.J.; Duke, R. Glucocorticoid activation of a calcium-dependent endonuclease in thymocyte nuclei leads to cell death. J. Immunol. 1984, 132, 38-42. [PubMed]

44. Burton, K. A study of the conditions and mechanism of the diphenylamine reaction for the colorimetric estimation of deoxyribonucleic acid. Biochem. J. 1956, 62, 315. [CrossRef] [PubMed] 
45. Denault, J.-B.; Salvesen, G.S. Human caspase-7 activity and regulation by its N-terminal peptide. J. Biol. Chem. 2003, 278, 34042-34050. [CrossRef] [PubMed]

46. Barbareschi, M.; Caffo, O.; Veronese, S.; Leek, R.D.; Fina, P.; Fox, S.; Bonzanini, M.; Girlando, S.; Morelli, L.; Eccher, C. Bcl-2 and p53 expression in node-negative breast carcinoma: A study with long-term follow-up. Hum. Pathol. 1996, 27, 1149-1155. [CrossRef]

47. Onur, R.; Semerciöz, A.; Orhan, I.; Yekeler, H. The effects of melatonin and the antioxidant defence system on apoptosis regulator proteins (Bax and Bcl-2) in experimentally induced varicocele. Urol. Res. 2004, 32, 204-208. [CrossRef]

48. Poncelet, D.; Lencki, R.; Beaulieu, C.; Halle, J.; Neufeld, R.; Fournier, A. Production of alginate beads by emulsification/internal gelation. I. Methodology. Appl. Microbiol. Biotechnol. 1992, 38, 39-45. [CrossRef]

49. Higuchi, T. Mechanism of sustained-action medication. Theoretical analysis of rate of release of solid drugs dispersed in solid matrices. J. Pharm. Sci. 1963, 52, 1145-1149. [CrossRef]

Sample Availability: Samples of the compounds are available from the authors.

(C) 2019 by the authors. Licensee MDPI, Basel, Switzerland. This article is an open access article distributed under the terms and conditions of the Creative Commons Attribution (CC BY) license (http://creativecommons.org/licenses/by/4.0/). 